\title{
A REVIEW OF POSSIBILITIES FOR CONTROL OF Salmonella AND OTHER PATHOGENIC BACTERIA IN PIG FEED
}

\author{
Đuro M. Vukmirović*, Slađana M. Rakita, Nedeljka J. Spasevski, Bojana M. Kokić, Vojislav V. Banjac, \\ Ivana S. Čabarkapa \\ University of Novi Sad, Institute of Food Technology, 21000 Novi Sad, \\ Bulevar cara Lazara 1, Serbia
}

\author{
*Corresponding author: \\ Phone: +381214853796 \\ Fax: +38121450725 \\ E-mail address: djuro.vukmirovic@fins.uns.ac.rs
}

\begin{abstract}
Each category of pigs is susceptible to diseases caused by pathogenic bacteria, which negatively reflects on animal health, farm production results or meat quality. Animal feed is one of the potential reservoirs of pathogenic bacteria and infection source of domestic animals. Salmonella spp. is major microbiological hazard in animal feed. Thus, there is importance for implementation of strategies for preventing feed contamination with Salmonella, by minimizing dust, maximizing hygiene of space and processing equipment in feed mills and implementing control measures in each stage of feed production. Existing Salmonella feed contamination can be eliminated by conditioning and later different heat treatments (pelleting, extrusion, expansion) in production process while changing physical structure of the feed (coarsely or finely ground mash or pellets) can influence on conditions for Salmonella development in gastrointestinal tract of pigs. Contamination of feed by pathogenic bacteria and conditions for their development can be also controlled by addition of acidifiers, prebiotics, probiotics and, more recently, essential oils of plant origin, into feed. Various strategies for prevention of feed bacterial contamination, processes for feed decontamination, as well as possibilities for controlling pathogenic bacteria, especially Salmonella, in pig feed were presented and discussed in this article.
\end{abstract}

Key words: pig feed, pathogenic bacteria, Salmonella, contamination

\section{INTRODUCTION}

According to EFSA (2008) Salmonella spp. was pointed out as the major hazard for microbial contamination of animal feed, followed by Listeria monocytogenes, Echerichia coli O157:H7, and Clostridium sp. Between 15 and $20 \%$ of Salmonella infections in humans are caused by contaminated pig meat (Jansen et al., 2007). Oil seed meals and animal derived protein are major sources of Salmonella contamination of animal feed (Wierup, 2013). Regulation 2160/2003 of the EU outlined the need for developing proper measures for detection and control of Salmonella at all stages of production (EFSA, 2008).

Concerning that feed can be contaminated with Salmonella which can cause animal contamination, it is very important to include strategies for prevention of contamination and recontamination of feed and to eliminate existing contamination (Arguello et al., 2012). In this respect, some countries even prescribed mandatory programs for control of Salmonella, e.g. heat treatments (Sauli et al., 2005). Additionally, Salmonella can be controlled by dif- 
ferrent feeding strategies, i.e. physical structure of feed (coarse or fine, mash or pelleted). These strategies create unfavorable conditions for Salmonella within the gastrointestinal tract of pigs, while at the same time growth of normal bacterial microbial flora is promoted. Beneficial microflora prevents Salmonella growth by lowering $\mathrm{pH}$ of the digesta and/or by producing anti-Salmonella compounds and metabolites (Arguello et al., 2012).

Contaminated feed and newly purchased pigs are the most significant sources of infection in pig breeding. The weaning pigs are production category that is most often infected by Salmonella, which usually causes disease. On the other hand, adult pigs are also susceptible to infection but rarely show clinical signs and thus can enter slaughtering process which results in contaminated meat (Sauli et al., 2005).

All feed ingredients can be a potential source of Salmonella. For this reason, decontamination steps are important to prevent spreading of contaminated feed to animals. Different decontamination procedures are applied in practice, e.g. heat treatments (Maciorowski et al., 2007), the use of organic acids (Papenbrock et al., 2005) or other chemical preservatives (Rouse et al., 1988).

\section{SALMONELLA IN FEED MILLS}

Animal feeds (complete diets and single feedstuffs), if contaminated by Salmonella, are important source of contamination in animals (Sanchez et al., 2002). An issue related to control of Salmonella presence in feed is lack of uniformity of its distribution throughout the material. Consequently, several hundreds of samples are sometimes necessary to determine contamination level accurately (Jones and Richardson, 2004). Need to analyze high amount of samples for Salmonella contamination and high expenses of testing make sampling difficult (Jones, 2011). According to Mitchell and McChesney (1991) at least 30 samples must be analyzed to reliably determine if the given batch of feed is Salmonella negative. For this reason, it could be recommendable to use indirect indicators of Salmonella presence, such as Enterobacteriaceae, concerning that Salmonella belongs to Enterobacteriaceae family (Jones and Richardson, 2004; Vukmirović et al., 2013). Enterobacteriaceae counts higher than $10^{4} \mathrm{cfu} / \mathrm{g}$ in unprocessed feeds and higher than $10^{2} \mathrm{cfu} / \mathrm{g}$ in processed feeds may be indicators of Salmonella presence (Jones and Richardson, 2004).

Dust is the most important source of Salmonella contamination within the feed mill (Butcher and Miles, 1995). For this reason it is very important to control dust in feed mills from the very beginning of the feed production, i.e. from the unloading process where the largest quantity of dust is produced (Jones, 2011). Additional points of dust formation that must be controlled within the feed mills are grinders, mixers, elevator legs, conveyers, pellet scalpers (McDaniel, 2005). Morita et al. (2006) indicated feed mill operators as the main contamination conduit and outlined that it is important to designate areas within the plant as dirty and clean and to limit the flow of personnel, equipment and air inbetween these areas. Fats protect Salmonella from environmental and physical stresses and it is hard to eliminate Salmonella from the areas containing fat accumulation (Morita et al., 2006; D'Aoust, 2007). Reduction of fat accumulation in the mill will decrease Salmonella survival and spreading (Jones, 2011). Additional vectors for spreading of Salmonella and other pathogen bacteria are rodents (Morita et al., 2006) and birds, and control measures regarding this must be implementted (Jones, 2011).

Area of receiving raw ingredients can be pointed out as area of the heaviest Salmonella contamination, therefore control efforts should be especially focused in this part of feed plant (Jones, 2011). Additionally, poorly designed or maintained grinding systems may result in intensive heat emission during grinding action causing moisture present in the material to migrate and concentrate, resulting in condensation. This will create favorable conditions for microorganism proliferation (Jones, 2008). An interesting survey of Salmonella presence in different parts of feed mill by Shrimpton (1989) indicated feedstuffs of animal origin, mixer and pel- 
let conditioner as the points with the highest occurrence of Salmonella.

Multiplication of bacteria in processing equipment has been considered the major source of Salmonella in feed. At critical temperature and moisture conditions, multiplication of bacteria can occur in certain regions of a feed mill creating a major point of feed contamination. Consequently, adequate measures and processing procedures must be applied and become routine in feed manufacturing (Ziggers, 2003). Without adequate control measures, Salmonella can become endemic in a feed mill and extremely difficult to eradicate due to formation of biofilms on the surfaces of the equipment (Davies and Wales, 2010).

\section{HYDROTHERMAL TREATMENTS}

Feed ingredients can be contaminated in feed mills, transport vehicles or during feed storage (Kidd et al., 2002). If Salmonella and other pathogen microorganisms are present in feed ingredients, multiplication can occur during storage. The most commonly used method for prevention of microbial growth in feed components and compound feed is drying (Binter et al., 2011). Control of moisture content within the feed mill is essential for Salmonella control. Drying of cereal grains to moisture content $13-14 \%$, and drying of oil seeds to $7-9 \%$ effectively prevents microbial proliferation. Moisture content of pig feed formulas is usually between 7.5 and $14 \%$ resulting in water activity level (expressed as Aw value) between 0.40 and 0.65 which inhibits microorganism growth (Eisenberg, 2007). Regarding Salmonella, keeping the Aw values bellow 0.94 will prevent its growth (Bell and Kyriakides, 2002). Salmonella can survive for long periods in dry material, and will multiply rapidly in presence of moisture. Consequently, it is very important to keep dry conditions in storage and in manufacture line (Sauli et al., 2005).

Salmonella is usually killed at temperatures higher than $55^{\circ} \mathrm{C}$ but high concentrations of fat, starch and protein in feed form colloid layer that protect bacteria and increase its heat resistance. Consequently, temperatures higher than $80-85^{\circ} \mathrm{C}$ are used in feed industry to achieve hygieni- sation effect (Hoh, 2010). Different heat treatments (pelleting, extrusion and expansion) can reduce Salmonella and other pathogen microorganisms in feed. The application of hydrothermal treatments (primarily steam conditioning and pelleting) is optional in pig feed production. The main reason for applying these processes is to prevent segregation of feed components, to increase digestibility, to hygienise the feed etc. (Binter et al., 2011). Even though hygienisation is not the primary reason for hydrothermal treatment of pig feed, it is also one of the important consequences of moist heat application. Hydrothermal treatments do not result in complete destruction of microorganisms in the feed (sterilization) but rather in pasteurization, i.e. in reduction of total germ count and in killing of all pathogen microorganisms (Kersten et al., 2005).

The pelleting process consists of conditioning (mixing steam and water with mash feed), pelleting (pressing conditioned material through die openings of the pellet press) and cooling (removing heat and moisture). Conditioning is considered as the most important phase of the pelleting process where combination of temperature, moisture and retention time reduces number of microorganisms in feed concurrently with preparing the mash for agglomeration in the pellet press. Temperature higher than $80^{\circ} \mathrm{C}$ is necessary for elimination of Salmonella and other coliform bacteria during steam conditioning process while spore-forming bacteria can be resistant to pelleting temperatures higher than $90^{\circ} \mathrm{C}$ (Veldman et al., 1995; Jones and Richardson, 2004). Conditioning is usually few seconds to several minutes (Thomas et al., 1997) but more recent constructions of conditioners enabled extending of conditioning time to enhance hygienisation of feed and improve product quality (Ziggers, 2003). Applying $80-85^{\circ} \mathrm{C}$ for 30 min eliminated all Enterobacteriaceae from feed (Kampelmacher, 1981). When temperatures higher than $85^{\circ} \mathrm{C}$ are applied for one minute during conditioning and pelleting, Salmonella should be completely eliminated (Veldman et al., 1995; Jones and Richardson, 2004). Besides temperature, decontamination 
efficiency of thermal treatments depends also of moisture content of feed and of treatment time. Destruction of Salmonella Enteritidis at temperature of $82.2{ }^{\circ} \mathrm{C}$ was increasing with increase of the residence time in the conditioner and with increasing the moisture content of feed (Himathongkham et al., 1996). Cover et al. (1985) suggested steam conditioning before pelleting at a temperature of at least $82.2^{\circ} \mathrm{C}$ at a moisture level of $18 \%$. In the research of Maciorowski et al. (2007), optimal temperature, time and moisture of feed conditioning process, in order to destroy Salmonella and E.coli, were $85.7^{\circ} \mathrm{C}, 4.1 \mathrm{~min}$ and $14.5 \%$ feed moisture content.

Expanders and extruders could also be used in the production of pig feed, weather for processing of single feed stuffs or for processing of complete diets. Extruders and expanders are similar machines but expanders do not possess die with openings at the product exit and thus produce unshaped product. In the expanders, the moisture content, shear stress and production costs are lower compared to extrusion (Thomas et al., 1999; Prestløkken and Fôrutvikling, 2013). The extrusion and expansion processes are also known as HTST (high temperature and short time) processes, and during these processes generally higher temperatures and pressures are applied on the mash (Goodarzi Boroojeni et al., 2016) which results in more effective elimination of pathogen bacteria.

Thermal processed feed is at a great risk to be re-contaminated after thermal processing, i.e. during cooling, transportation, and storage, with the cooling step as a major point for recontamination. This is due to high amount of dust that is forming during cooling the agglomerated product with high air volumes. Dust collected from the coolers has greater contamination levels compared to dust from the other locations in the feed plant. Additionally, condensated water inside the cooler is another trigger for increased risk of recontamination due to increased moisture level inside the cooler which creates favorable conditions for growth of Salmonella and other pathogen bacteria (Jones and Richardson, 2004; Jones, 2011). Organic acid inclusion is an option for prevention of feed recontamination with non-spore forming bacteria (Jones, 2011; Goodarzi Boroojeni et al., 2014). According to Maciorowski et al. (2004), combination of heat and acid treatment (e.g. propionic acid) is shown to be more effective compared to these treatments alone.

\section{ESSENTIAL OILS}

Since the use of antimicrobial growth promoters in pig feed has been banned in EU (regulation EC/1831/), essential oils have received increased attention as potential alternatives to in-feed antibiotics. They are plant secondary metabolites which contain complex mixture of volatile compounds with variable chemical compositions and concentrations ( $\mathrm{Li}$ et al., 2012). It has been recognized that some essential oils can be used as antimicrobial agents because of their ability to control foodborne pathogens (Burt et al., 2004). It was also found that within the gastrointestinal tract, they provoke secretion of digestive enzymes and increase gastrointestinal tract motility (Westendarp, 2005).

It is difficult to make generalizations about the mode of action of essential oils on bacteria because essential oils contain different groups of chemical compounds, and hence, their antibacterial activity cannot be attributed to one specific mechanism. Mechanisms of action of essential oils on bacterial cell consider degradation of the cell wall, disintegration of membrane structure, leakage of ions and other cytoplasmic constituents, coagulation of cytoplasm, which leads to collapse of the proton motive force (Burt et al., 2004).

Essential oils with well-documented antimicrobial properties are those which contain phenolic compounds, such as carvacrol, thymol and eugenol, but also other substances such as cinnamaldehyde, thyme, phenylpropane, limonene, geraniol and citronellal (Borsoi et al., 2011; Franz et al., 2009). The antimicrobial activity of phenolic essential oils is ascribed to their delocalized electrons and the hydroxyl group on the phenolic ring (Burt et al., 2004). Thymol and carvacrol interact with the cell membrane by $\mathrm{H}$ bonding, 
causing the increased permeability of membranes and mitochondria, disintergration of the outer cell membrane and inhibition of the gram negative bacteria ( $\mathrm{Di}$ Pasqua et al., 2007).

Essential oils demonstrated a certain degree of selectivity. It is generally believed that gram-negative bacteria are slightly less susceptible to the action of essential oils than gram-positive bacteria (Burt et al., 2004). When conducted in vitro test, Si et al. (2006) reported that essential oils showed a high inhibition toward pure cultures of Salmonella, with little effect on beneficial gut bacteria in mediums that consisted of pig cecal digesta. Ouwehand et al. (2010) found that the most effective essential oils at reducing growth of Salmonella were carvacrol, cinnamaldehyde, citral and thymol.

However, in an animal experiment which included piglets challenged with Salmonella, essential oils had no effect on the reduction of Salmonella shedding when added to the diet at the concentration close to their minimum bactericidal concentrations (Si et al., 2006b). The abolition of anti-microbial activity of essential oils after mixing with the diets was hypothesized to be the consequence of their binding to the feed particles (Si et al., 2006b). Oils which are generally hydrophobic, bound to the fats and other feed constitutes in pig diets, and thereby become unavailable to affect intestinal microbiota. In piglets, essential oils were showed to be absorbed almost completely in the stomach and the proximal part of small intestine within $2 \mathrm{~h}$ after oral administration (Michiels et al., 2008). In order to exert their anti-microbial activity in the pig's gastrointestinal tract, essential oils need to be protected. Micro-encapsulation of the oils before adding to the diet could be a valuable strategy to overcome this problem (Lallès et al., 2009).

Michiels et al. (2011) tested the addition of carvacrol and thymol into the piglet diet and found that these oils did not affect major bacteria of the pig foregut, but reduced the number of intra-epithelial lymphocytes and the ratio of villus height/crypt depth in the distal part of small intestine, indicating an improved gut health. The influence of thymol addition to a starter diet was analyzed in pigs with or without Sallmonela challenge (Trevisi et al., 2007). Thymol did not reduce faecal shedding of Salmonella, but it protected against a rise in body temperature 1-day post challenge. The final body weight after 29 days of experiment was not affected by thymol; however, feed intake was reduced. In a study of Manzanilla et al. (2004), piglets were fed a combination of essential oils with carvacrol and cinnamaldehyde together with capsaicin and reported an increased gastric retention time of ingested feed, which resulted in better nutrient absorption. Similarly, it was observed that essential oils could improve the activity of digestive enzymes and cause increased nutrient absorption, resulting in a better feed conversion ratio (Windisch et al., 2008). It was found that encapsulated essential oils containing thymol and cinnamaldehyde reduced the incidence of diarrhea by $50 \%$ and enhanced the immune status of newly weaned pigs. The addition of essential oils also improved the performance of piglets, resulting in greater growth rate and improved feed conversion rate ( $\mathrm{Li}$ et al., 2012).

\section{ACIDIFICATION}

Addition of acids in animal feed, besides prevention of recontamination, has a supportive effect on the health of gastrointestinal tract of pigs and enhances nutrient digestibility. The addition of acids reduces $\mathrm{pH}$ and buffering capacity of the diet, reduces $\mathrm{pH}$ in the stomach which promotes digestion of proteins, promotes growth of beneficial bacteria and reduces growth of pathogenic bacteria in the intestines (Close, 2000). For the acidification of the pig feed, both inorganic and organic acids can be used. The inorganic acids possess only the effect of reducing $\mathrm{pH}$ value by releasing hydrogen ions $\left(\mathrm{H}^{+}\right)$, while organic acids, besides hydrogen ion, release an anion that has direct inhibitory effect on pathogen bacteria (Klausing and Riewenherm, 2010). Numerous research results proved that the inclusion of organic acids in pig diets reduces number of Enterobacteria in gastrointestinal tract (Canibe et al., 2005; Papenbrock et al., 2005; Kluge 
et al., 2006). Organic acid supplementation was initially introduced in feed for weaned piglets for prevention of postweaning diarrhea and to improve growth performance in piglets (Sutton et al., 1991), but later it was observed that acidification also beneficially affects the performance of fattening pigs and sows. On the other hand, disadvantages of feed acidification are high costs per tonne of produced feed, corrosive action of acids and consequent damage of the equipment, and negative influence of acids on feed flavor which could decrease animal feed consumption (Ziggers, 2003).

Different organic acids display specific antimicrobial activities, e.g. lactic acid poses good antimicrobial activity, sorbic acid has an antimold effect, while formic and propionic acids shows both antibacterial and antifungal effect (Partanen and Mroz, 1999; Dibner and Buttin, 2002). The organic acids have been used for many years in commercial feed production mostly as feed preservatives. Formic and propionic acid are used most frequently but also lactic, citric, fumaric and sorbic acids and their salts serve as feed preservatives (Lückstädt and Mellor, 2011).The organic acids are usually used in the form of their sodium, potassium or calcium salts because salts are easier to handle due to their solid form, lower volatility, lesser corrosiveness and better solubility in water compared to free acids (Partanen and Mroz, 1999). The salts of the organic acids do not possess pH-reducing effect, only the antimicrobial effect. Additionally, these salts are good sources of minerals (Klausing and Riewenherm, 2010).

One of practical limitations of using the organic acids may be their prompt metabolism and/or absorption upon entering the duodenum. This can be overcome by using so-called encapsulated or protected organic acids. Microencapsulation enables protecting of active compounds, with protective matrix (i.e. fat coating) delaying the dissociation of active molecules in the stomach. In this way, organic acids will reach intestine where present enzymes will dissolve fat or other type of coating as it passes along the intestine and release the active compound (Piva et al., 2007; de Lange et al., 2010).

Reduction of acid binding capacity of feed has a similar effect as the acid addition. Acid binding capacity of feed can be reduced using different strategies, e.g. decreasing the calcium content to be $<0.85 \%$, the use of calcium formiate as a source of calcium, decreasing protein content below $18 \%$ with concurrent using of synthetic amino acids. Acid binding capacity can be reduced also by decreasing level of phosphorus below $0.45 \%$ while at the same time addition of phytase will secure phosphorus digestibility from plant phytate (Klausing and Riewenherm, 2010).

\section{PHYSICAL STRUCTURE OF THE FEED}

According to numerous research results, physical structure of pig feed, i.e. pelleted or not, coarsely or finely ground, has an important influence on Salmonella occurrence in gastrointestinal tract of pigs. Even though pelleting, as thermal treatment process, can reduce microbial contamination in compound feed, it has been well documented that non-pelleted feed has a protective effect against Salmonella compared to use of pelleted feed (Jørgensen et al., 1999; Rajic et al., 2007; García-Feliz et al., 2009). Similarly, coarsely ground mash has a protective effect compared to fine ground mash pig feed (Jørgensen et al., 1999; Jørgensen et al., 2001; Mikkelsen et al., 2004). Coarsely ground mash feed_results in undamaged tissue of esophageal region in pigs' stomach, while both fine grinding and pelleting cause certain degree of tissue damage which sometimes led to gastric ulcers (Nielsen and Ingvartsen, 2000; Mikkelsen et al., 2004). If pigs are fed with coarsely ground feed, the passage rate in the stomach will be slower, dry matter content of the stomach increases, the number of total anaerobic bacteria is increased, concentration of different organic acids is increased resulting in lower $\mathrm{pH}$ value in the stomach. The slower gastric passage rate of pigs fed coarsely ground mash feed may result in higher microbial fermentation in the stomach as a consequence of increased time of bacteria to proliferate in 
the stomach. Coarsely ground mash feed creates physical conditions (more solid gastric content) in the stomach that stimulate growth of anaerobic bacteria. This results in increased production of organic acids and in low $\mathrm{pH}$ in the stomach that kills E. Coli and Salmonella (Mikkelsen et al., 2004; Klausing, 2010).

Even (uniform) acidification of digesta in the stomach is very important in respect to presence of pathogenic intestinal bacteria. Salmonella and $E$. coli have neutral to slightly alkaline $\mathrm{pH}$ optimum. The range of $\mathrm{pH}$ in pig's stomach is between 2 and 4 but it can be compromised by the amount and form of ingested feed (Klausing, 2010). Mash feed is consumed in smaller portions by the pigs during the day compared to the pelleted feed. Consequently, the quantity of feed in the stomach will be larger if the animals are fed pellets. Additionally, pellets require more time to dissolve which will all result in insufficient and uneven acidification of feed in the stomach (Klausing, 2011).

In some parts of digesta, $\mathrm{pH}$ may reach the value of 7 or more, which is ideal condition for Salmonella and E. coli. Uneven acidification of feed in stomach will cause fluctuating secretion of bicarbonates from pancreas into the duodenum which may result in $\mathrm{pH}$ value above 8 in duodenum and this creates optimal conditions for Gram-negative pathogenic bacteria (Klausing, 2010).

Combination of low $\mathrm{pH}$ and high concentration of lactic acid in the stomach reduced number of Salmonella entering small and large intestine in pigs (Mikkelsen et al., 2004). When pigs were fed coarse ground mash feed, Salmonella presence was significantly reduced compared to pigs fed pelleted feed (Jørgensen et al., 1999).

Using of coarse ground mash to produce pellets also reduced Salmonella presence in the pigs, but the level of detection was not as low as for pigs fed coarse ground mash feed. In the research of Mikkelsen et al. (2004), higher concentration of butyric acid was observed in ceca and colon of pigs fed coarsely ground feed, with butyric acid promoting epithelial cell growth.

\section{PREBIOTICS AND PROBIOTICS}

Probiotics are live microorganisms that, when administrated in a certain amount, exert beneficial health effects in the host animal by improving intestinal microbial balance (Callaway et al., 2010). Probiotics have been shown to stimulate the development of a healthy microbiota, inhibit the growth and dissemination of pathogenic microorganisms, improve gut tissue maturation, stimulate mucosal immunity, enhance digestive capacity and lower the $\mathrm{pH}$ in gastrointestinal tract of young piglets (de Lange et al., 2010). Most commonly used probiotics are members of lactic acid bacteria, particularly Lactobacillus and Bifidobacterium which are normally present in the gut. Administration of Lactobacillus and Bifidobacterium, immediately after birth, stimulates the growth of a beneficial microbiota capable of inhibiting colonization of enteric pathogens in premature neonatal piglets (Siggers et al., 2008). Collado et al. (2007) investigated in vitro protective effect of Bifidobacterium and Lactobacillus on the adhesion of pathogenic bacteria to swine intestinal mucosa. They revealed that the probiotics, alone or in combination, reduced the adherence of Salmonella. In combination, these probiotics enhanced each other's adhesion, mainly in large intestinal mucosa. The mixture of five strain probiotics mixture containing Lactobacillus and Pediococcus reduced pathogen shedding in weaned piglets challenged with Salmonella. The administered probiotic bacteria also reduced incidence, severity, and duration of diarrhea (Casey et al., 2007).

Probiotics Enterococcus faecium and $E$. faecalis are often utilized in clinical trials regardless they have not been proposed for the concept of Qualified Presumption of Safety by the European Union (EFSA, $2007)$. The supplementation of $E$. faecium to the feed of pregnant sows and piglets affected the early intestinal bacterial colonization of suckling piglets which is reflected in the reduced enteropathogenic bacterial load (Scharek et al., 2005).) Piglets treated with Enterococcus faecalis were less able to defend themselves against Salmonella infection, as showed by increased fecal excretion and coloni- 
zation of Salmonella in organs. However, the probiotic treatment resulted in greater production of specific antibodies against Salmonella (Szabó et al., 2009).

Probiotic group called competitive exclusion involves the utilization of intestinal bacterial culture prepared from the gut content of the healthy adult animal (Gaggia et al., 2010). Neonatal pigs treated with bacterial competitive-exclusion culture derived from the cecal contents of healthy pigs shed significantly lower pathogen numbers after challenge with Salmonella, and also showed reduced numbers of Salmonella bacteria in the gut (Genovese et al., 2003). Fedorka-Cray et al. (1999) observed reduced Salmonella counts in cecal contents and at the ileocolic junction in Salmonella challenged weaning piglets fed a competitive exclusion culture derived from the mucosa of healthy pigs.

Prebiotics are non-digestible food ingredients which beneficially affect the host by stimulating the growth health-promoting bacteria (mainly bifidobacteria and lactobacilli) in colon (Tanner et al., 2014). Commonly used prebiotics in animal feed are oligosaccharides with different molecular structure. It was reported that galactooligosaccharide mixture inhibited the adherence of Salmonella and E. coli to HT29 cells in vitro (Tzortzis et al., 2005). Addition of the mixture at $4 \%$ to a pigs' diet, increased the density of bifidobacteria and the acetate concentration, and decreased the $\mathrm{pH}$ value.

In comparison to probiotics, prebiotics are cheaper and easier to manipulate and include into diets. Symbiotic effect of prebiotics and probiotics can enhance the efficacy of probiotic effect on the health of gut microbiota (de Lange et al., 2010).

\section{CONCLUSIONS}

For controlling Salmonella and other pathogenic bacteria contamination in pig feed, prevention is first and much important step by assuring implementation of control measures in feed mills during all feed production stages. If the feed is inevitably contaminated, there is array of various techniques for feed decontamination such as thermal treatments, addi- tion of acidifiers, prebiotics, probiotics and essential oils in feed, as well as feeding strategies by changing physical structures of feed in order to minimize animal infections. Selection of proper strategy for decontamination and prevention of recontamination depends on level of feed contamination, feed type, available process equipment and additives and costs.

\section{ACKNOWLEDGEMENTS}

This paper is a result of the research within the project TR31034 financed by the Ministry of Education, Science and Technological Development, Republic of Serbia.

\section{REFERENCES}

1. Arguello, H., Rubio, P., Carvajal, A. (2012). Salmonella control measures at farm in swine production. In Salmonella - Distribution, Adaptation, Control Measures and Molecular Technologies. Eds. B.A. Annous, J.B. Gurtler, InTech, pp. 99-122.

2. Bell, C., Kyriakides, A. (2001). Salmonella: A Practical Approach to the Organism and Its Control in Foods, Blackwell Science.

3. Binter, C., Straver, J.M., Häggblom, P., Bruggeman, Lindqvist, P.A., Zentek, J., Andersson, M.G. (2011). Transmission and control of Salmonella in the pig feed chain: A conceptual model. International Journal of Food Microbiology, 145, S7-S17.

4. Buick, I. (2000). Heat treatment systems in feed mills. Feed Compounder, 20 (10), 20-23.

5. Burt, S. (2004). Essential oils: Their antibacterial properties and potential applications in foods - a review. International Journal of Food Microbiology, 94, 223-253.

6. Butcher, G.D., Miles, R.D. (1995). Minimizing Microbial Contamination in Feed Mills Producing Poultry Feed. Coop. Ext. Serv. Publ. No. VM93. University of Florida, Gainesville.

7. Callaway, T.R., Edrington, T.S., Anderson, R.C., Harvey, R.B., Genovese, K.J., Kennedy, C.N., Venn, D.W., Nisbet, D.J. (2008). Probiotics, prebiotics and competitive exclusion for prophylaxis against bacterial disease. Animal Health Research Reviews, 9, 217-225.

8. Canibe, N., Højberg, O., Højsgaard, S., Jensen, B.B. (2005). Feed physical form and formic acid addition to the feed affect the gastrointestinal ecology and growth perfomance of growing pigs. Journal of Animal Science, 83, 12871302.

9. Casey, P.G., Gardiner, G.E., Casey, G., Bradshaw, B., Lawlor, P.G., Lynch, P.B., Leonard, F.C., Stanton, C., Ross, R.R., Fitzgerald, G.F., Colin, H., (2007). A five-strain probiotic combination reduces pathogen shedding and alleviates disease signs in pigs challenged with Salmonella enterica Serovar Typhimurium. Ap- 
plied and Environmental Microbiology, 73, 1858-1863.

10. Close, W.H. (2000). Producing pigs without antibiotic growth promoters. Advances in Pork Production, 11, pp. 47.

11. Collado, M.C., Grześkowiak, Ł., Salminen, S. (2007). Probiotic strains and their combination inhibit in vitro adhesion of pathogens to pig intestinal mucosa. Current Microbiology, 55, 260265.

12. Cover, M.S., Gary, J.T., Binder, S.F. (1984). Reduction of standard plate counts, total coliform counts and salmonella by pelletizing animal feed. International Symposium on Salmonella, New Orleans, LA, Proceedings, pp. 221231.

13. Davies, R.H., Wales, A.D. (2010). Investigations into Salmonella contamination in poultry feed mills in the United Kingdom. Journal of Applied Microbiology, 109, 1430-1440.

14. D'Aoust, J.Y. (1997). Salmonella species. In Food microbiology: Fundamentals and frontiers. Eds. M.P. Doyle, L.R. Beuchat, T. J. Montville, ASM Press, Washington DC, pp. 129-158.

15. de Lange, C.F.M., Pluske, J., Gong, J., Nyachoti, C.M. (2010). Strategic use of feed ingredients and feed additives to stimulate gut health and development in young pigs. Livestock Science, 134, 124-134.

16. Di Pasqua, R., Betts, G., Hoskins, N., Edwards, M., Ercolini, D., Mauriello, G. (2007). Membrane toxicity of antimicrobial compounds from essential oils. Journal of Agriculture and Food Chemistry, 55, 4863-4870.

17. Dibner, J., Buttin, P. (2002). Use of organic acids as a model to study the impact of gut microflora on nutrition and metabolism. Journal of Applied Poultry Research, 11, 453-463.

18. Eisenberg, S. (2007). Relative stability of selenites and selenates in feed premixes as a function of water activity. Journal of AOAC International, 90, 349-353.

19. European Community (EC) European Regulations No. 1831 (2003). Community Register of Feed Additives (2008).

20. (EFSA) European Food Safety Authority (2007). Introduction of a Qualified Presumption of Safety (QPS) approach for assessment of selected microorganisms referred to EFSA Opinion of the Scientific Committee (Question No EFSA-Q-2005-293). Adopted on 19 November 2007. The EFSA Journal, 587, 1-16.

21. (EFSA) European Food Safety Authority (2008). Microbiological risk assessment in feedingstuffs for food-producing animals. Scientific Opinion of the Panel on Biological Hazards. The EFSA Journal, 720, 1-84.

22. Fedorka-Cray, P.J., Bailey, J.S., Stern, N.J., Cox, N.A., Ladely, S.R. Musgrove, M. (1999). Mucosal competitive exclusion to reduce Salmonella in swine. Journal of Food Protection, 62, 1376-1380.

23. Franz, C., Baser, K.H.C., Windisch, W. (2010). Essential oils and aromatic plants in animal feeding - a European perspective - A review. Flavor and Fragrance Journal, 25, 327-340.
24. Gaggìa, F., Mattarelli, P., Biavati, B. (2010). Probiotics and prebiotics in animal feeding for safe food production. International Journal of Food Microbiology, 141, S15-S28.

25. García-Feliz, C., Carvajal, A., Collazos, J.A., Rubio, P. (2009). Herd-level risk factors for faecal shedding of Salmonella enterica in Spanish fattening pigs. Preventive Veterinary Medicine, 91, 130-136.

26. Genovese, K.J., Anderson, R.C., Harvey, R.B., Callaway, T.R., Poole, T.L., Edrington, T.S., Fedorka-Cray, P.J., Nisbet, D.J. (2003). Competitive exclusion of Salmonella from the gut of neonatal and weaned pigs. Journal of Food Protection, 66, 1353-1359.

27. Goodarzi Boroojeni, F., Svihus, B., von Reichenbach, H.G., Zentek, J. (2016). The effects of hydrothermal processing on feed hygiene, nutrient availability, intestinal microbiota and morphology in poultry - A review. Animal Feed Science and Technology, 220, 187-215.

28. Goodarzi Boroojeni, F., Vahjen, W., Mader, A., Knorr, F., Ruhnke, I., Röhe, I., Hafeez, A., Villodre, C., Männer, K., Zentek, J. (2014). The effects of different thermal treatments and organic acid levels in feed on microbial composition and activity in gastrointestinal tract of broilers. Poultry Science, 93, 1440-1452.

29. Himathongkham, S., Pereira, M.D.G., Riemann, H. (1996). Heat destruction of Salmonella in poultry feed: effect of time, temperature, and moisture. Avian Diseases, 40, 72-77.

30. Hoh, S. (2010). New dimension in the production of hygienised feed meal. Grain and Feed Milling Technology, November-December, 14-16.

31. Jansen, A., Frank, C., Stärk, K. (2007). Pork and pork products as a source for human salmonellosis in Germany. Berliner und Münchener Tierärztliche Wochenschrift, 120, 340346.

32. Jones, F.T., Richardson, K.E. (2004). Salmonella in commercially manufactured feeds. Poultry Science, 83, 384-391.

33. Jones, F.T. (2008). Quality control in feed manufacturing. Feedstuffs, 80 (38), 72-76.

34. Jones, F.T. (2011). A review of practical Salmonella control measures in animal feed. Journal of Applied Poultry Research, 20, 102-113.

35. Jørgensen, L., Dahl, J., Wingtrand, A. (1999). The effect of feeding pellets, meal and heat treatment on the Salmonella-prevalence of finishing pigs. $3^{\text {rd }}$ International Symposium on Epidemiology and Control of Salmonella in Pork, Washington D.C., USA, Proceedings, pp. 308-312.

36. Jørgensen, L., Kjærsgaard, H.D., Wachamann, H., Jensen, B., Knudsen, B. (2001). Effect of pelleting and use of lactic acid in feed on Salmonella prevalence and productivity in weaners. $4^{\text {th }}$ International Symposium on the Epidemiology and Control of Salmonella in Pork, Leipzig, Germany, Proceedings, pp. 109-111.

37. Kampelmacher, E.H., Guinée, P.A.M., van Schothorst, M., Willems, H.M.C.C. (1965). Experimental studies to determine the tempera- 
ture and duration of heat treatment required for decontamination of feed meals. Zentralblatt für Veterinärmedizin Reihe B, 12 (1), 50-54.

38. Kersten, J., Rohde H.R., Nef, E. (2005). Principles of Mixed Feed Production. Bergen/Dumme, Agrimedia, Germany.

39. Kidd, R.S., Rossignol, A.M., Gamroth, M.J. (2002). Salmonella and other Enterobacteriaceae in dairy-cow feed ingredients: antimicrobial resistance in Western Oregon. Journal of Environmental Health, 64 (9), 9-16.

40. Klausing, H.K. (2010). How feeding can support intestinal health (1)? All About Feed, 1 (1), 2730.

41. Klausing, H.K., Riewenherm, G. (2010). How feeding can support intestinal health (2)? All About Feed, 1 (3), 30-31.

42. Klausing, H.K. (2011). A closer look at feed structure. All About Feed, 2 (4), 18-19.

43. Kluge, H., Broz, J., Eder, K. (2006). Effect of benzoic acid on growth performance, nutrient digestibility, nitrogen balance, gastrointestinal microflora and parameters of microbial metabolism in piglets. Journal of Animal Physiology and Animal Nutrition, 90, 316-324.

44. Lallès, J.P., Bosi, P., Janczyk, P., Koopmans, S.J., Torrallardona, D. (2009). Impact of bioactive substances on the gastrointestinal tract and performance of weaned piglets: a review. Animal, 3, 1625-1643.

45. Li, S.Y., Ru, Y.J., Liu, M., Xu, B., Péron, A., Shi, X.G. (2012). The effect of essential oils on performance, immunity and gut microbial population in weaner pigs. Livestock Science, 145, 119-123.

46. Lückstädt, C., Mellor, S. (2011). The use of organic acids in animal nutrition, with special focus on dietary potassium diformate under European and Australasian conditions. Recent Advances in Animal Nutrition Australia, 18, 123130.

47. Maciorowski, K.G., Herrera, P., Jones, F.T., Pillai, S.D., Ricke, S.C. (2007). Effects on poultry and livestock of feed contamination with bacteria and fungi. Animal Feed Science and Technology, 133 (1-2), 109-136.

48. Maciorowski, K.G., Jones, F.T., Pillai, S.D., Ricke, S.C. (2004). Incidence, sources, and control of food-borne Salmonella spp. in poultry feeds. World's Poultry Science Journal, 60 (4), 446-457.

49. Manzanilla, E.G., Perez, J.F., Martin, M., Kamel, C., Baucells, F., Gasa, J. (2004). Effect of plant extracts and formic acid on the intestinal equilibrium of early-weaned pigs. Journal of Animal Science, 82, 3210-3218.

50. McDaniel, G.L. (2005). Dust collection systems. In Feed Manufacturing Technology. Eds. V.S.K. Schofield, Am. Feed Ind. Assoc., Arlington, VA, pp. 230-238.

51. Michiels, J., Missotten, J., Dierick, N., Fremaut, D., Maene, P., De Smet, S. (2008). In vitro degradation and in vivo passage kinetics of carvacrol, thymol, eugenol and transcinnnamaldehyde along the gastrointestinal tract of piglets. Journal of Science of Food and Agricultrure, 88, 2371-2381.
52. Michiels, J., Missotten, J., van Hoorick, A., Ovyn, A., Fremaut, D., De Smet, S., Dierick, N. (2011). Effects of dose and formulation of carvacrol and thymol on bacteria and some functional traits of the gut in piglets after weaning. Archives of Animal Nutrition, 64, 136-154.

53. Mikkelsen, L.L., Naughton, P.J., Hedemann, M.S., Jensen, B.B. (2004). Effects of physical properties of feed on microbial ecology and survival of Salmonella enterica serovar Typhimurium in the pig gastrointestinal tract. $A p$ plied Environmental Microbiology, 70, 34853492.

54. Mitchell, G.A., McChesney, D.G. (1991). A plan for Salmonella control in animal feeds. In Proceedings on the Diagnosis and Control of Salmonella. US Anim. Health Assoc., Richmond, VA, USA, pp. 28-31.

55. Morita, T., Kitazawa, H., lida, T., Kamata, S. (2006). Prevention of Salmonella cross-contamination in an oilmeal manufacturing plant. Journal of Applied Microbiology, 101, 464-473.

56. Nielsen, E. K., Ingvartsen, K.L. (2000). Effect of cereal type, disintegration method and pelleting on stomach content, weight and ulcers and performance in growing pigs. Livestock Production Science, 66, 271-282.

57. Ouwehand, A.C., Tiihonen, K., Kettunen, H., Peuranen, S., Schulze, H., Rautonen, N. (2010). In vitro effects of essential oils on potential pathogens and beneficial members of the normal microbiota. Veterinarni Medicina, $55,71-78$.

58. Papenbrock, S., Stemme, K., Amtsberg, G., Verspohl, J., Kamphues, J. (2005). Investigations on prophylactic effects of coarse feed structure and/or potassium diformate on the microflora in the digestive tract of weaned piglets experimentally infected with Salmonella Derby. Journal of Animal Physiology and Animal Nutrition, 89, 84-87.

59. Partanen, K.H., Mroz, Z. (1999). Organic acids for performance enhancement in pig diets. Nutrition Research Reviews, 12, 117-145.

60. Peñalver, P., Huerta, B., Borge, C., Astorga, R., Romero, R., Perea, A. (2005). Antimicrobial activity of five essential oils against origin strains of the Enterobacteriaceae family. APMIS, 113, 1-6.

61. Piva, A., Pizzamiglio, V., Morlacchini, M., Tedeschi, M., Piva, G. (2007). Lipid microencapsulation allows slow release of organic acids and natural identical flavors along the swine intestine. Journal of Animal Scence, 85, 486493.

62. Prestløkken, E., Fôrutvikling, F. (2013). Expander Treatment. HFE 305 Feed Manufacturing Technology

(http://www.umb.no/statisk/iha/kurs/nova/feed $t$ echnology/4.pdf).

63. Rajic, A., O'Connor, B.P., Deckert, A.E., Keenliside, J., McFall, M.E., Re-Smith, R.J., Dewey, C.E., McEwen, S.A. (2007). Farm-level risk factors for the presence of Salmonella in 89 Alberta swine-finishing barns. Canadian Journal of Veterinary Research, 71, 264-270. 
64. Rouse, J., Rolow, A., Nelson, C.E. (1988). Effect of chemical treatment of poultry feed on survival of Salmonella. Poultry Science, 67, 1225-1228.

65. Sauli, I., Danuser, J., Geeraerd, A.H., Van Impe, J.F., Rüfenacht, J., Bissig-Choisat, B., Wenk, C., Stärk, K.D.C. (2005). Estimating the probability and level of contamination with Salmonella of feed for finishing pigs produced in Switzerland-the impact of the production pathway. International Journal of Food Microbiology, 100, 289-310.

66. Sanchez, S., Hofacre, C.L., Lee, M.D., Maurer, J.J., Doyle, M.P. (2002). Animal sources of salmonellosis in humans. Journal of the American Veterinary Medical Association, 221, 492-497.

67. Scharek, L., Guth, J., Reiter, K., Weyrauch, K.D., Taras, D., Schwer, P., Schierack, P., Schmidt, M.F.G., Wieler, L.H., Tedin, K. (2005). Influence of a probiotic Enterococcus faecium strain on development of the immune system of sows and piglets. Veterinary Immunology and Immunopathology, 105, 151-161.

68. Shrimpton, D.H. (1989). The Salmonella problem of Britain. Milling Flour and Feed, January 1989, 16-17.

69. Si, W., Gong, J., Chanas, C., Cui, S., Yu, H., Caballero, C., Friendship, R.M. (2006a). In vitro assessment of antimicrobial activity of carvacrol, thymol and cinnamaldehyde towards Salmonella serotype Typhimurium DT104: effects of pig diets and emulsification in hydrocolloids. Journal of Applied Microbiology, 101, 1282-1291.

70. Si, W., Gong, J., Tsao, R., Zhou, T., Yu, H., Poppe, C., Johnson, R., Du, Z. (2006b). Antimicrobial activity of essential oils and structurally related synthetic food additives towards selected pathogenic and beneficial gut bacteria. Journal of Applied Microbiology, 100, 296-305.

71. Siggers, R.H., Siggers, J., Boye, M., Thymann, T., Mølbak, L., Leser, T., Jensen, B.B., Sangild, P.T. (2008). Early administration of probiotics alters bacterial colonization and limits dietinduced gut dysfunction and severity of necrotizing enterocolitis in preterm pigs. Journal of Nutrition, 138, 1437-1444.

72. Sutton, A.L., Mathew, A.G., Scheidt, A.B., Patterson, J.A., Kelly, D.T. (1991). Effects of carbohydrate sources and organic acids on intestinal microflora and performance of the weanling pig. $5^{\text {th }}$ International Symposium on Digestive Physiology in the Pigs, Wageningen, The Netherlands, Proceedings, pp. 422-427.

73. Szabó, I., Wieler, L.H., Tedin, K., Scharek-Tedin, L., Taras, D., Hensel, A., Appel, B., Nöckler, K. (2009). Influence of a probiotic strain of Enterococcus faecium on Salmonella enterica Serovar Typhimurium DT104 infection in a porcine animal infection model. Applied and Environmental Microbiology, 75, 26212628.
74. Tanner, S.A., Chassard, C., Berner, A.Z., Lacroix, C. (2014). Synergistic effects of Bifidobacterium thermophilum RBL67 and selected prebiotics on inhibition of Salmonella colonization in the swine proximal colon PolyFermS model. Gut Pathogens, 6 (44), 1-12.

75. Thomas, M., van Zuilichem, D.J., van der Poe, A.F.B. (1997). Physical quality of pelleted animal feed. 2. Contribution of processes and its conditions. Animal Feed Science and Technology, 64, 173-192.

76. Thomas, M., Huijnen, P.T.H.J., van Vliet, T., van Zuilichem, D.J., van der Poel, A.F.B. (1999). Effects of process conditions during expander processing and pelleting on starch modification and pellet quality of tapioca. Journal of the Science of Food and Agriculture, 79, 1481-1494.

77. Trevisi, P., Merialdi, G., Mazzoni, M., Casini, L., Tittarelli, C., De Filippi, S., Minieri, L., LalattaCosterbosa, G., Bosi, P. (2007). Effect of dietary addition of thymol on growth, salivary and gastric function, immune response, and excretion of Salmonella enterica Serovar Typhimurium, in weaning pigs challenged with this microbe strain. Italian Journal of Animal Science, 6 (suppl. 1), 374-376.

78. Tzortzis, G., Goulas, A.K., Gee, J.M., Gibson, G.R. (2005). A novel galactooligosaccharide mixture increases the bifidobacterial population numbers in a continuous in vitro fermentation system and in the proximal colonic contents of pigs in vivo. Journal of Nutrition, 135, 17261731.

79. Veldman, A., Vahl, H.A., Borggreve, G.J., Fuller, D.C. (1995). A survey of the incidence of Salmonella species and Enterobacteriaceae in poultry feeds and feed components. Veterinary Record, 136, 169-172.

80. Vukmirović, Đ., Čabarkapa, I., Kokić, B., Sredanović, S., Spasevski, N., Lević, J., Čolović, R. (2013). Decontamination effects of extrusion processing in feed production. III International Conference „Sustainable Postharvest and Food Technologies“, Vrnjačka Banja, Serbia, Proceedings, pp. 250-255.

81. Westendarp, H. (2005). Essential oils for the nutrition of poultry, swine and ruminants. Deutsche Tierarztliche Wochenschrift, 112, 375-380.

82. Wierup, M. (2013). Salmonella in feed. In Salmonella in Domestic Animals. Eds. P. Barrow, U. Methner, CABI International, UK, pp. 377398.

83. Windisch, W., Schedle, K., Plitzner, C., Kroismaayr, A. (2008). Use of phytogenic products as feed additives for swine and poultry. Journal of Animal Science, 86, E140-E148.

84. Ziggers, D. (2003). Time and temperature control feed hygiene. Feed Technology, 5 (6), 11-15. 


\section{ПРЕГЛЕД МОГУЋНОСТИ ЗА КОНТРОЛУ Salmonella И ДРУГИХ ПАТОГЕНИХ БАКТЕРИЈА У ХРАНИ ЗА СВИњЕ}

Ђуро М. Вукмировић*, Слађана М. Ракита, Недељка Ј. Спасевски, Бојана М. Кокић, Војислав В. Бањац, Ивана С. Чабаркапа

Универзитет у Новом Саду, Научни институт за прехрамбене технологије у Новом Саду, 21000 Нови Сад, Булевар цара Лазара бр. 1, Србија

Сажетак: Свака категорија свиња склона је болестима које узрокују патогене бактерије што се негативно одражава на здравље животиња, производне резултате на фрармама или квалитет меса. Храна за животиње представља један од потенцијалних резервоара патогених бактерија и извор инфекције домаћих животиња. Salmonella spp. је велика микробиолошка претња храни за животиње. Зато је важна имплементација стратегија за превенцију контаминације хранива салмонелом попут смањења настале прашине и побољшања хигијене простора и процесне опреме у фабрикама хране за животиње, као и испуњење контролних мера у свакој фази производње. Постојећа контаминације хране за животиње салмонелом може се елиминисати применом поступка кондиционирања и термичких процеса (пелетирања, екструдирања и експандовања) који обично следе у производњи, док се променом физичког облика хране за свиње (грубо или фино млевена смеса, пелетирана смеса) може утицати на услове за развој салмонеле у гастроинтестиналном тракту свиња. Контаминација хранива патогеним бактеријама такође може да се контролише додатком закисељивача, пребиотика, пробиотика, као и, у скорије време, етеричних уља у храну за свиње. У овом раду приказани су и продискутовани различити приступи за контролу, превенцију, и елиминисање контаминације патогеним бактеријама, са нарочитим акцентом на Salmonella spp.

Кључне речи: храна за свиње, патогене бактерије, Salmonella, контаминација

Received: 9 October.2017

Accepted: 22 November.2017 